\title{
On the Meanings and Uses of Urban Space in the Arab City. An Historical Perspective
}

\author{
Nezar AlSayyad \\ University of California, Berkeley, United States of America \\ nezar@berkeley.edu
}

This special issue of The Journal of Public Space deals with the idea of re-visioning places of public gathering in the Contemporary Arab City. The three keywords or concept in this formulation are the "Arab city", and "Public gathering" and "urban place or space". It is worthwhile to spend some time interrogating each of these concepts by themselves and in a relationship to each other. We may first ask what is the Arab city? Is it a city that is truly different from its counterparts in much of the global south? It is different from the non-Arab Middle East, or for that matter other cities in the developed world that underwent substantial changes over during the last few decades. Equally important is to posit the question regarding the types of public gatherings that occur in the Arab city today which require a specific spatial accommodation. And finally, it is essential to inquire about the nature of urban space in the so-called Arab city and to interrogate how this space is used to accommodate, contain and sometimes even to restrict different forms of public activities.

As an urban historian who has spent much of the last three decades studying Arab urbanism, I believe history sometimes offers a perspective or a method to address some of these questions although it may not offer us real answers. On the issue of the Arab city, it is important to recognize that there has never been a prototypical city in the Arab world. The Arab world was not and still is not a homogenous urban realm and its different peoples, nations and political regimes have produced cities of different sizes, different densities, different sub-cultures and different levels of wealth. In fact, it is common today to find certain cities in Arab-speaking North Africa that have a lot more in common with cities elsewhere in the Global South in terms of culture and social life than other Arab cities. Similarly, some cities of the Arabian-Persian Gulf that have more in common with cities Global North in terms of infrastructure and economy. Historically this may not have always been the case. Decades ago, the late scholar Janet Abu-Lughod brilliantly argued that one always knows when one is in the presence of a Muslim culture. The images, the sounds, the smells, and the social interaction between people in public are what makes the Muslim City, she suggested. A similar argument may be made today about Arab cities being unified under one category in which people's interaction in space and the language of the street may provide more 
commonalities than differences. Hence, it becomes legitimate to speak of intersections of spaces and activities in the Arab city as long as one is willing to account for the great diversity that may exist between them.

If we turn to the second question which deals with the nature of public gatherings in the contemporary Arab city, we encounter a similar dilemma. It is part of human nature for people to want to get together in public and in large numbers to celebrate certain national and religious occasions, cultural festivals, and sometimes to engage in political protest. The initial success of the Arab spring was touted by many as a reminder of the importance of urban open space for public gatherings. Subsequently, the Arab Spring failed to bring about any significant political or structural changes to the countries of the Arab world that experienced it. However, this failure shouldn't be viewed as a failure of the mechanisms of political mobilization or of the qualities of open space. Instead, some have attributed this outcome to the failed methods and practices of public gatherings under political regimes that are fundamentally intolerant of the notion of publicness altogether and particularly of public political dissent.

We now come to our final question regarding the nature of urban open space in the Arab city and its relationship to urban activities. Here history offers us an interesting perspective. We know that there is a strong relationship between the socio-political structure of a society and the type of urbanism it creates. Societies that have very clear distinctions between their political, commercial and religious institutions as represented by specific buildings like in the Medieval European city have created open spaces that parallels this institutional structure. On the other hand, societies that had a more subtle connection and intertwined relationships between its different institutional bodies, like the Arab city, have created incongruent urban spaces that do not clearly represent the power structure of these societies. This may make it more difficult to link the urban open spaces of the Arab city to specific symbolic representations of power.

There are a few well established mechanisms to map and analyse open space in the city. Architects and urban designers have usually favoured the use of the figure-ground approach because in quantified the relationship between the built masses and the voids between them revealing significant formal qualities. Based on this approach, one may identify four types of open spaces in the traditional Arab city. First, there are the Maidans, sometime also referred to as Sahas. These were open spaces that existed outside of the city gates and in few cases inside the city, fronting a major function like a palace or a Friday Mosque. They often accommodated Friday and Eid prayers, and later on the day would serve as weekend or seasonal markets. A second type, sometimes called Rahbas or 'Atfas, are smaller irregular spaces that occurred in front of Mosque, Madrasas and other religious structures inside the city and were surrounded by small shops and informal vending activities in different times of the day. The third type are small courtyard-like spaces sometimes called a hoshs located in the alleyways of the traditional residential quarters or Haras, and used mainly for neighbourhood purposes. And finally, there is the Qasbah, the linear pathway or thoroughfare that often extends from one gate to another and contains the main bazaar. It was the most important circulation space in the city who width varied based on the functions it served making it wide in certain places and very narrow in others.

A different way of looking at public gatherings in the traditional Arab city is not to start with the standard typology of open spaces discussed above but instead to focus on the nature of urban activity that required public gatherings and identify the open spaces that 
accommodated them. In this regard, we may observe that unlike traditional Greek or Roman towns, large open space seldom existed in the traditional Arab city. The Maidan was not equivalent to the Greek Agora or the Roman forum and it did not perform the same function of providing an arena for public gatherings. The Friday Mosque provided that place where the community could possibly meet to discuss matters of life, state and religion. Except for festivals celebrating victories and preparations for wars, political activity in the traditional Arab city did not require public gatherings. It usually involved only smaller groups of elite individuals and occurred inside buildings.

Commercial activity on the other hand took place everywhere in the Arab city but specialized markets and commerce in valuable goods was mainly conducted in the bazaar, or the Qasbah. This was the main spine which still exists until today in the old quarters of many Arab cities and was the hub of socio-economic interaction. On it also lay the most important religious and administrative buildings as it was the social, religious and commercial spine of the city. This was the case for cities that were built by the Arabs like Basra and Kufa in Iraq or cities that were occupied by them during the Islamic conquest like Damascus or Aleppo. In the few cases, where the bazaar did not stretch on the main spine, it occupied an entire quarter that was specifically designated to accommodate its activities.

Islam was the predominant religion in most Arab cities and Muslim religious rituals did not require any particular urban space. Early mosques were simply open spaces not buildings that accommodated the congregation of believers. As the Muslim population of Arab cities grew, large spaces that were designated to accommodate overflow crowds for Friday and Eid prayers. In a few instances these spaces, which were often on the outskirts of the city and not in central sites, got formalized over time in these marginal locations. But space in the Arab city changed over time. Colonial presence, and foreign occupations changed the traditional Arab city as it introduced European style spaces like squares, piazzas and boulevard. The emergence of these spaces also facilitated the emergence of modern functions and new activities like clubs and malls, that were used by the rising elites and over time these new structures replaced the traditional coffee houses and the bazaars.

If we are to move forward and try to apply this historical perspective to understand contemporary Arab cities, two important attributes become very clear. First is the realization that the main public gatherings that are tolerated in the cities of the Arab world today by most regimes are those that mainly relate to social events and recreational activity. In fact, in recent years public gatherings for religious activity or for sports viewing were often monitored, limited or banned by governments out of concern and fear that they would delve into politics and create a protest against the political establishment. Second, it has also become clear that public gatherings for the purpose of exercising political protest or presenting popular demands can no longer be held in physical open space in most Arab cities under regimes that have mastered the control of public space. Indeed, today there are many laws on the books in many Arab countries today that simply prohibit any form of public gathering except those organized by the regime. Today, such public activities have moved to the virtual medium, a matter that allowed some observers to dub the takeover of public squares during the Arab spring as 'Facebook" revolutions. Indeed, this trend which may have started in the cities of the Arab World has now spread all over the world as social media has become the main platform not only for political dissent but also for social mobilization. This is the 
reality of the world today, and such activities are likely to gain further strength in the aftermath of the COVID-19 crisis.

It is my conviction that those of us interested in the study of public gatherings and open space in the Arab World have to turn our attention to the interwoven relationship between social media and social movements. One major lesson from the Arab Spring is that organizing public gatherings will require serious engagement with virtual social media. Indeed, the spatial and temporal aspects of the protests that brought about the Arab Spring suggest that the reciprocal interaction between social media, traditional media and urban space is going to be the wave of the future. This formulation does not simply reproduce relations between these actors, but it also transforms them over time and in the process, it may transform the forms and practices of Arab urbanism itself. Time will tell.

\section{References}

Abu-Lughod, J. (1987) "The Islamic City--Historic Myth, Islamic Essence, and Contemporary Relevance," International Journal of Middle East Studies, 19(2) pP I55-I68.

AlSayyad, N. (2016) "The Arab City, the Middle Eastern City, the Islamic City: Reflections on a Concept." In Saliba, R. (ed.) Re-Conceptualizing Boundaries: Urban Design in the Arab World. London: Ashgate, pp. 3I-43.

Alsayyad, N. and Guvenc, M. (20I4) "Virtual Uprisings: On the Interaction of New Social Media, Traditional Media Coverage and Urban Space during the 'Arab Spring,' Urban Studies 5 I (3) PP. I-I7.

Alsayyad, N. and Bristol K. (1992) "Levels of Congruence: On Urban Space and the Institutional Structure of Different Societies" Journal of Architecture and Planning Research 9(3) pp.193-206.

AlSayyad, N. (1987) "Space in an Islamic City: A Case Study," Journal of Architecture and Planning Research 4(I2) Pp. I08-II9.

To cite this article:

AlSayyad, N. (202I) On The Meanings and Uses of Urban Space in The Arab City. An Historical Perspective, The Journal of Public Space, 6(I), 5-8, DOI I0.3289I/jps.v6il.I457

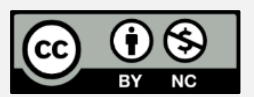

This work is licensed under a Creative Commons Attribution - Non Commercial 4.0 International License https://creativecommons.org/licenses/by-nc/4.0/ 